\title{
Moro Reflex
}

National Cancer Institute

\section{Source}

National Cancer Institute. Moro Reflex. NCI Thesaurus. Code C81311.

An involuntary, primal response in the neonate to loud noise or the feeling of falling. The response is characterized by the infant's arms symmetrically spreading out to the side and then back to the midline, and involuntarily flexing the fingers and toes. 